with self-recording gauges. The rainfall over this vast area varies very greatly, according to position and altitude and the strength of the monsoons. On the whole, the amounts for 1907 differed little from the average; in Java the extreme yearly values were about 29 inches and $196 \frac{1}{2}$ inches (both in the eastern part), and at outlying stations about $2 \mathrm{I}$ inches to $197^{\frac{1}{2}}$ inches (both in Celebes). The results at more than 700 stations in Java, including the observations at non-official stations, for the period I879-1905, have recently been separately published by Dr. W. van Bemmelen. In addition to the above-mentioned publications, the observatory has issued the results of several valuable investigations relating to seismology, tides, \&c., and has completed a magnetic survey of the whole archipelago. Papers have also been published bearing upon the moon's influence on meteorological and magnetial phenomena.

\section{RECENT PAPERS ON FISHES.}

A REVIEW, by Mr. E. W. L. Holt, of recent contributions to our knowledge of the life-history of the eel, forms the subject of No. 8 of Irish Fisheries Scientific Investigations fo: 1907 (1909). After a survey of the development and migration of the species, the author is of opinion that the brecding-resort of the eels of northern Europe is in the deep water outside the 500-fathom line to the south-west of Ireland, where alone their leptocephali have been taken in abundance. It by no means follows from this that all north European eels which reach the sea succeed in arriving at the breeding-area, and possibly Finnish ecls never breed at all. If this be so, it becomes a practical certainty that elvers-unlike salmon - do not return to the rivers from which their parents started, as, indeed, is improbable on other grounds, seeing that eels-unlike salmon-are hatched in the sea.

In the second part of vol. xxxi. of Notes from the L.cyden Museum, Prof. Max Weber, of Amsterdam, describes a large number of new species of fishes collected by the members of the Siboga Expedition in Austro-Malaya. A large proportion of these were taken in littoral or sublittoral waters, but others were captured on coral-reefs or in deep water with nets. Many of the new forms are blennies and gobies, no fewer than seven new species of the type-genus (Gobio) of the latter group being described. The present preliminary notice is published on account of the interest attaching to these fishes from a distributional point of vicw.

To vol. vii., part i., of Annotationes Zoologicae laponenses. Mr. S. Tanaka contributes two papers on Japanese fishes, one dealing with those inhabiting rockpools at Misaki, and including descriptions of two new species, while the second is devoted to eight new species from Japan generally, two of these being gobies and one a blenny.

Finally, three new species of cisco, or lake-herrings, of the genus Argyrosomus from the great lakes of North America are described by Messrs. Jordan and Evermann in No. 1662 of the Proceedings of the U.S. National Museum (vol. xxxvi., pp. $165^{-172}$ ), where a note is appended on the species of white fish (Coregonus) inhabiting the same region.

\section{UNIVERSITY AND EDUCATIONAL INTELLIGENCE.}

Birmingham.-Sir E. Ray Lankester, K.C.B., has resigned his appointment as Huxley lecturer for the coming session, and Mr. W. Bateson, F.R.S., has accepted an invitation to fill the vacancy thereby caused.

On July 7 the King is to perform the opening ceremony of the new buildings of the University. These buildings, which are situate in the south-west corner of Edgbaston, are about three miles from the centre of the town. They comprise the Great Hall, an imposing structure about 160 feet in length, 8o feet in width, and 6o feet high ; two separate blocks devoted to engineering in its various branches, civil, mechanical, and electrical; another block for mining and metallurgy, with additional buildings for

$$
\text { No. } 2064 \text {, VOL. } 80]
$$

the manufacture and working of iron and steel; and a power-station for the generation of electrical power, which is distributed to the different blocks for driving machinery and for lighting purposes. These sections have all been in working order for two or three years; and at the present time there are approaching completion two blocks for the departments of physics and chemistry respectively, and a third structure which will serve the function of a central library. Rising high above all these is the Chamberlain Tower, with its clock and bells, measuring from base to summit about 325 feet, the gift of a local donor as a tribute to the Chancelior of the University.

CAMBRIDGE.- - In connection with the Darwin centenary, it is proposed to confer the degree of Doctor of Science, honorts causa, upon:-E. van Beneden, professor of zoology in the Lniversity of Liège; Robert Chodat, professor of botany in the University of Geneva; Francis Darwin, F.R.S., of Christ's College; Karl F. von Goebel, professor of botany in the University of Munich; L. von Graff, professor of zoology in the University of Gratz; H. Hottding, professor of philosophy in the University of ropenhagen ; ]. Loeb, professor of physiology in the University of California, Berkeley; E. Perrier, director of the Natural History Museum, Paris; G. A. Schwalbe, professor of anatomy in the University of Strassburg; H. von Vöchting, professor of botany in the University of Tuibingen; H. de Vries, professor of botany in the University of Amsterdam; C. D. Walcott, secretary of the Smithsonian Institution, Washington; E. B. Wison, prufessor of zoology in the Columbia University of New York; and C. R. Zeiller, professor of palxobotany in the Ecole Nationale Supérieure des Mines, Paris.

The special board for biology and geology has approved a grant of $25 l$. from the Balfour fund made by the managers to $\mathrm{Mr}$. R. C. Punnett, in furtherance of his experiments to investigate the inheritance of certain features in rabbits.

The syndicate on alternatives for the general examination, after consultation with the special boards affected, recommends that the schedules for the first examination for the M.B. degree be adopted for the proposed preliminary examination in science, and that the examinations be conducted by the same cxaminers and on the same papers. It is proposed to allow that the three subjects of the examination-chemistry, physics, and elementary biology - be taken separately, but all candidates must pass in each subject. Detailed regulations have been issued as regards the amendment of the ordinances which the various suggestions will invo!ve.

The new agricultural buildings are now well advanced, and it is hoped they will be ready for occupation by October. The amount of expenditure already incurred is $14,000 l$. and it is now necessary to obtain specifications and estimates for furniture and fittings. It is estimated that these, together with the architect's commission and incidental expenses, will amount to 3500 . At the present time the building fund amounts to $17,000 l$., and there is thus a balance of $3000 l$. in hand. A further sum of $2000 \%$. has been promised as soon as $18,000 l$. has been subscribed. Strenuous efforts are therefore being made to obtain the coool. required to reach this amount.

London.-Wednesday, May I2, was Presentation Day at the University. In the absence of the Chancellor (Lord Rosebery), the Vice-Chancellor (Sir Wm. Collins, M.P.) presided. Before the proceedings in the Great Hall commenced, the first gencral parade of the University contingent of the Officcrs' Training Corps, which mustered more than 400 strong, was held in front of the University. Addresses were delivered by the Vice-Chancellor and by Sir Henry Mackinnon, Director-General of the Territorial Force. The first report of the new principal, Dr. H. A. Miers, F.R.S., showed continued progress, the number of matriculants having risen from 3277 in $1907-8$ to 38.96 in $1908-9$. A corresponding increase was also reported in the number of first degrees granted (from II92 to I336) and of higher degrees (from 64 to 78 ). In concluding his report, the principal directed attention to the great progress which had been made in the organisation of higher education in London since the re-constitution of the University, and the "appalling deficiencies "which still existed 
in certain particulars. "I found a university," he said, " housed in the half of a building which, though splendid, is entirely inadequate and bears another name, without any proper accommodation for its examinations, without even sufficient room for its normal business or for the meetings of its Senate, councils, and committees; a university which sorely needs endowments and buildings for advanced teaching and research; which has no place that can become a centre for the intellectual and social life of the teachers and students belonging to its numerous schools; a university mainly dependent upon examination fees for its existence, while compelled to consume one-half of these fees in the expenses of the examinations themselves." The presentees included 13 Doctors of Science and 26r Bachelors of Science. It is remarkable that the number of B.Sc.'s presented slightly exceeds the number of B.A.'s (254). In addition, 86 B.Sc.'s in engineering were presented.

The new physiology institute at University College, funds for the building of which were provided by the generosity of Mr. Ludwig Mond and Dr. Aders Plimmer and by the bequest of the late Mr. T. Webb, will be opened on June 18 by Mr. Haldane, Secretary of State for IVar.

THE King has signed the warrant for granting a charter establishing the University of Bristol.

LORD REAY will open the new buildings of the Merchant Venturers' Technical College, Bristol, on June 24 .

Mr. R. A. Cuisolm has been appointed (ireville research student for research in connection with the subject of cancer at Guy's Hospital Medical School.

THE old Galway students of Prof. Senier have just presented him with an address encased in a silver casket, expressing their pleasure at the recent action of the Royal University in conferring upon him the honorary degree of Doctor of Science in recognition of his services to science and to university education in Ireland.

We learn from Science that subscriptions to the C. W. Eliot fund have been received from about 2050 graduates of Harvard University and others, and amount at this time to about $26,000 l$. The committee hoped that the fund would amount to more than $30,000 l$. by May 19 , when President Eliot retired. The subscriptions have been placed in the hands of trustees, to invest and hold for the benefit of President and Mrs. Eliot. The fund will eventually pass to Harvard University.

THE Goldsmiths' Company recently offered a gift of $50,000 \mathrm{l}$. to the governors of the Imperial College of Science and Technology towards the cost of the proposed extension of the engineering department of the college, and on May I4 the offer was gratefully accepted by the governors. Writing to Lord Crewe, as chairman of the governors, Sir Walter Prideaux, on behalf of the Goldsmiths' Company, pointed out that the gift was irrespective of the company's support to the City and Guilds Institute, and that their subscriptions in the latter direction would not be curtailed. The letter reminded Lord Crewe that the whole of the engineering department of the Imperial College is to be called "The City and Guilds Collegc." The Goldsmiths' Company has expressed the hope that the company will be given separate representation on the delegacy which it is proposed shall administer the entire department of engineering, and the governors of the college have promised that the wishes of the company shall receive immediate attention. The Goldsmiths' Company will pay $x 0,000 l$. On the day whereon the contract for the work is signed, and the remainder by instalments spread over a period of not fewer than three years.

IN his annual address as president of the Royal Institution of Cornwall, Dr. R. Pearce discussed the attempts made by the society to provide instruction for miners in the subjects connected with their occupation. One of the objects of the institution, founded in 1818 , was to establish a mining school, the first of the kind in England. The results were at first unsatisfactory; but in 1859 the school was re-organised with the advice and assistance of $\mathrm{Mr}$. NO. 2064, VOL. 80]
R. Hunt, and at a later date by Sir C. Le Neve Foster. The result has been, not so much to improve the methods of Cornish mining, as to provide students qualified for work in other places. Out of 22 I students at the Camborne School only forty-one are Cornishmen, the balance being made up from natives of other parts of the country and several foreigners. The school has supplied mining engineers for the colonies and forcign countries, and the president, summing up the results, remarks :- "We may, I think, congratulate ourselves on the fact that, although Cornwall is not deriving any very important benefit by the application of scientific instruction to its mining industry, our colonies and our colonial mining and metallurgical enterprises are being built up from material furnished from our Cornish mining schools."

\section{SOCIETIES AND ACADEMIES. LONDON.}

Royal Society, May 13.-Sir Archibald Geskie, K.C.B., president, in the chair.-Recent solar research; Dr. G. E. Halo.- Utilisation of energy stored in springs: A. Mallock, F.R.S. The "dynamic worth" of a substance is the work which can be elastically stored in it, divided by its mass. It may be expressed either as. the square of the velocity which the stored work could impart to the mass, or, in gravity measure, as the height to which the stored work could raise the weight of the mass. The dynamic worth of india-rubber is more than ten times as great as for any other known substance, and for this reason india-rubber may be used with advantage in certain cases as a source of motive power. It is pointed out in the paper that if the potential energy in the strained material is to be efficiently converted into mechanical work, no frictional contact must occur while the strained material is returning to its original shape. Thus, if the strained material is in the form of a long cord wound on a reel (as the most convenient method of storage), the condition as to the absence of friction during contraction makes it necessary to develop the stored energy in cycles. In the first place, keeping the tension of the cord constant, a certain length must be unwound from the reel and the reel clamped. The cord also must be clamped in two places, first, near the place where it leaves the reel, and again at the extremity of the strained part, to some moving piece of the mechanism. If the part of the cord included between these points is then allowed to contract, the whole elastic work it contained is transferred to the machine. The above cycle may be repeated as long as any stretched cord remains on the reel. Any change of tension, however, in the process of unwinding involves loss of efficiency, due to the sliding of the cord on the reel or on the underlying coils, which must occur if the tension in the wound and unwound parts differs.-A new kind of glow in vacuum tubes: Rev. H. V. Gill. The experiments described in the paper were made with the object of investigating the nature and causes of a phenomenon observed by the writer when occupied with a research connected with palladium foil. A piece of palladium foil, or platinum foil coated with palladium black, is heated to a white heat in air at a pressure of about $0.15 \mathrm{~mm}$. A purple-blue glow is seen to surround the hot metal. Between the glow and the palladium there is a dark space. The thickness of the dark space varies with the temperature of the foil. The glow disappears when the tube is heated to a high temperature, and returns when it is cooled. It is shown that the presence of the glow depends on a reaction between the gases introduced into the tube when the palladium is heated and the disintegrated particles of palladium. Water vapour is required to be present in the tube, and the glow can be made to disappear by freezing out the vapour by means of a few drops of liquid air applied to the outside of the tube, or by introducing some phosphorous pentoxide into the tube. The spectrum of the glow shows certain regions which correspond to portions of the spectrum of carbon monoxide gas. It is also shown that carbon monoxide is present in the tube which shows the glow. No effect was observed when electric and magnetic fields were applied to the flow. The probable cause of the luminosity is the luminous union 